\title{
Structural Performance of the Integrated Oil Palm Loose Fruit Collector machine in Oil Palm Plantations
}

\author{
M.Z.M.Yusoff ${ }^{1 *}$, A.Zamri ${ }^{2}$, M.Z.A. Abd Kadir ${ }^{3}$, W. Z Wan Hassan ${ }^{4}$ and N. Azis ${ }^{5}$ \\ ${ }^{1}$ Sime Darby Plantation Research Sdn Bhd, Malaysia,zulfahmi.yusoff@simedarbyplantation.com \\ ${ }^{2}$ Sime Darby Plantation Research Sdn Bhd, Malaysia, zamri.yusof@ simedarbyplantation.com \\ ${ }^{3}$ Faculty of Engineering, University of Putra Malaysia, Malaysia, mzk@upm.edu.my \\ ${ }^{4}$ Faculty of Engineering, University of Putra Malaysia, Malaysia, wanzuha@ upm.edu.my \\ ${ }^{5}$ Faculty of Engineering, University of Putra Malaysia, Malaysia, norhafiz@ upm.edu.my
}

\begin{abstract}
Maximising the quantum of collected clean oil palm loose fruit is a major concern of all oil palm plantation owners. This is because if the loose fruit collection process is well and efficiently managed the benefits are very substantial, such as significantly higher oil extraction rate from much more total loose fruit collected that are relatively clean and debris-free. All this translates into substantial savings of what would normally be lost income. A machine, known as the "integrated loose fruit collector" (ILFC) machine was designed and fabricated to collect and clean loose fruit in an oil palm plantation. This machine was designed based on three main integrated systems: the vacuum system (to collect the loose fruit on the ground), the double-layer rotating drum system (to separate the loose fruit from debris), and the tipping bin system (which unloads the collected loose fruit by tipping them into an 8-metric-tonne bin using a hydraulic tipping cylinder). Design of these components required the assessment of structural integrity performance before being deployed in oil palm plantations. The structural integrity was performed using numerical simulation, which indicates that the ILFC machine was exposed to minimum induced stress distribution.
\end{abstract}

Key words: oil palm, loose fruit, oil extraction rate, mechanisation

\section{INTRODUCTION}

With a total planted area of oil palm at more than five million hectares, Malaysia is the second largest producer of palm oil in the world, after Indonesia [1-3]. In 2020, the industry on Malaysia is expected to contribute RM178 billion to the country's Gross Domestic Product and the key to this is the operational excellence of the oil palm industry. Operational excellence comes from the success of operational harvesting processes, which is the collection of loose fruit. This process is important since the loose fruit contribute significantly to the total amount of oil, provided they are not contaminated by debris, are properly managed and collected.
The uncollected LF offer the highest amount of OER as the fruits contain a high oil component. As reported in [4-7], a LF offers $40 \%$ of the OER per weight ratio or much higher in comparison with $20 \%$ to $25 \%$ of the OER per weight ratio provided by a fresh fruit bunch (FFB). One-way to increase or maintain the OER is by mechanised collection [8-9].

Mechanisation becomes an efficient method to collect the LF. It is estimated mechanisation may be able to:

- Improve the collection of oil palm LF from manual to semi- or fully-mechanised machines.

- Reduce the labour requirements for the collection of oil palm LF and increase productivity.

- Reduce multiple handling (i.e. collection and cleaning of oil palm LF) in management.

Hence, an initiative was taken to develop a suitable machine known as the "integrated oil palm loose fruit collector" machine (ILFC). The ILFC machine was designed, developed and fabricated which comprising three main components: vacuum collection component, double-layer rotating drum component, and tipping bin component. These configuration components required the assessment of structural performance before being deployed in the oil palm plantations.

The structural performance represents the objects and structures prone to fracture to describe an important problem in the case of failure in service, sometimes without warning, as in the case of welded structures [10-12]. This structural performance becomes a vital assessment to avoid unexpected and frequent serious failure of object or equipment in service. It can be done through theoretical analyses such as numerical simulation and proper testing [13]. Hence, this paper presents the structural performance of the developed ILFC machine using numerical simulation before the fabricated ILFC machine is tested in the field. The paper is organised as follows: more detailed research methods to deal with the numerical simulation of the ILFC structural performance. This is followed by the results and discussion section covering the structural performance of ILFC machine at normal and tipping positions, with and without load, and the conclusion that ends the section. 


\section{RESEARCH METHOD}

Numerical simulations were carried out by using Finite Element Analysis (FEA) software for the structural performance of ILFC machine before being tested in a field. The structural performance of ILFC machine was simulated based on structural performance integrity, which represents the stress distribution on the main chassis of the ILFC machine when it is subjected to carry the three main components vacuum collection component, double-layer rotating drum component, and tipping bin component as shown in Figure 1.

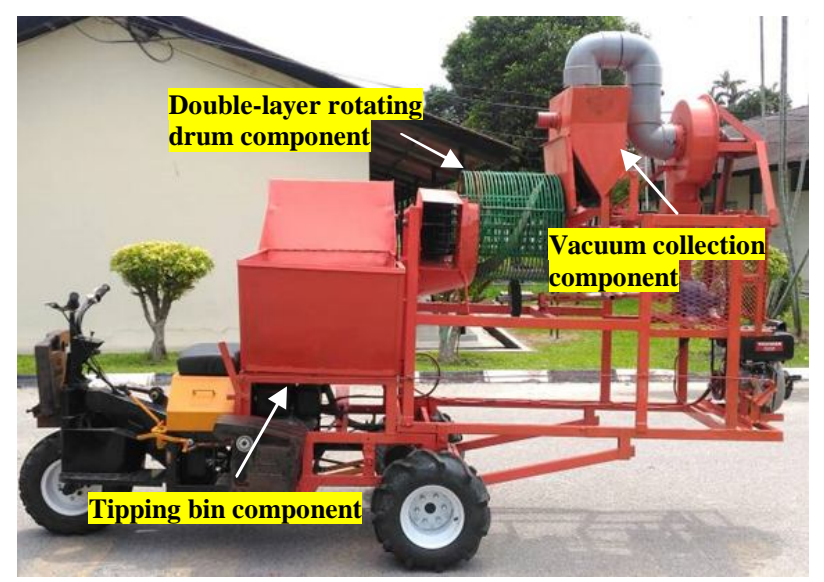

Figure 1: ILFC machine components

\subsection{ILFC Structural Integrity Analysis}

This paper focuses on the structural integrity of the ILFC chassis. Figure 2 shows the general modelling technique of the structural integrity study. The analysis was performed under the conditions as tabulated in Table 1 for four simulation conditions.

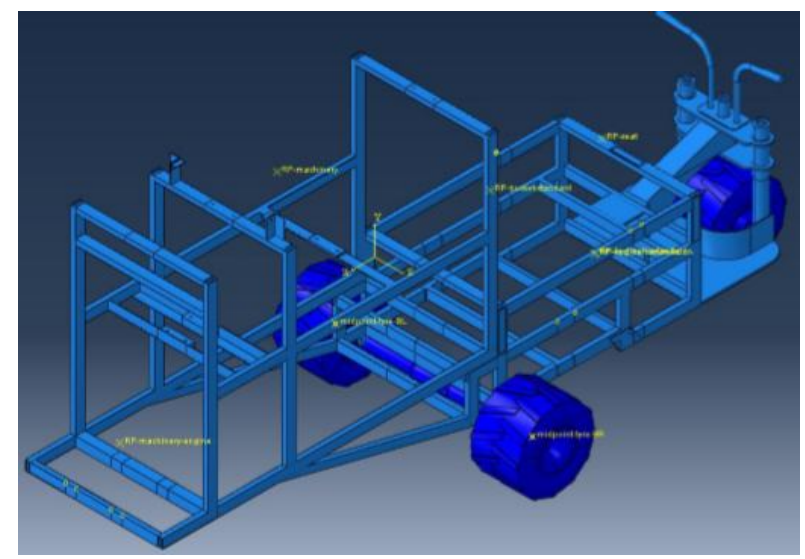

Figure 2: General modelling technique for ILFC structural integrity study
Table 1: Simulation conditions for ILFC structural integrity

\begin{tabular}{|c|l|c|}
\hline No. & Position of bucket in ILFC & Load in bucket (kg) \\
\hline 1 & ILFC Standard Position & 0 \\
\hline 2 & ILFC Standard Position & 200 \\
\hline 3 & ILFC Tipping Position & 0 \\
\hline 4 & ILFC Tipping Position & 200 \\
\hline
\end{tabular}

\subsubsection{Part Definitions}

The ILFC machine was modelled as a six-part model namely Body, Rim-Shaft-Front, Shaft-Rims-Back, Tyre-Front, Tyre-BR and Tyre-BL. The body was modelled as deformable body. The remaining components or the structure mounted on the chassis such as bucket, machinery, engine and others were modelled as "point masses" at their respective "centers of mass". Meanwhile, shafts, rims and tyre were modelled as the "display body". Table 2 summaries the related information with regard to the parts of the ILFC structural integrity study.

Table 2: Parts information for ILFC machine structural integrity study

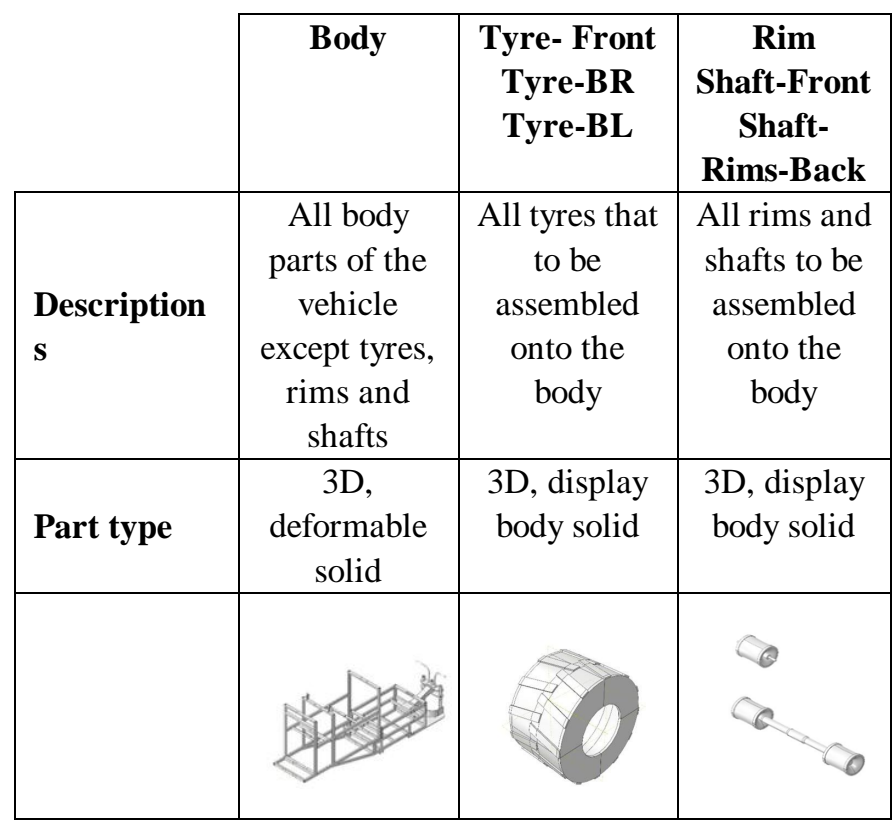

\subsubsection{Properties}

Material properties as shown in Table 3 were assigned as "a part of the Body" since the rest of the parts were set as "display body" only.

Table 3: Material properties for part Body.

\begin{tabular}{|l|l|}
\hline \multicolumn{1}{|c|}{ Properties } & \multicolumn{1}{c|}{ Body } \\
\hline Material & Mild steel \\
\hline $\begin{array}{l}\text { Material assigned in } \\
\text { Abaqus }\end{array}$ & Mild steel \\
\hline Density $\left(\mathrm{kg} / \mathrm{m}^{3}\right)$ & 7800 \\
\hline Elasticity $\left(\mathrm{N} / \mathrm{m}^{2}\right)$ & $200 \times 10^{9}$ \\
\hline Poisson's ratio & 0.25 \\
\hline Yield stress $\left(\mathrm{N} / \mathrm{m}^{2}\right)$ & $350 \times 10$ \\
\hline
\end{tabular}




\subsubsection{Assembly}

Figure 3 shows all the reference points assigned with point mass for ILFC machine standard and tipping position respectively. The yellow lines indicate that the masses are a constraint to the vehicle structure (body).

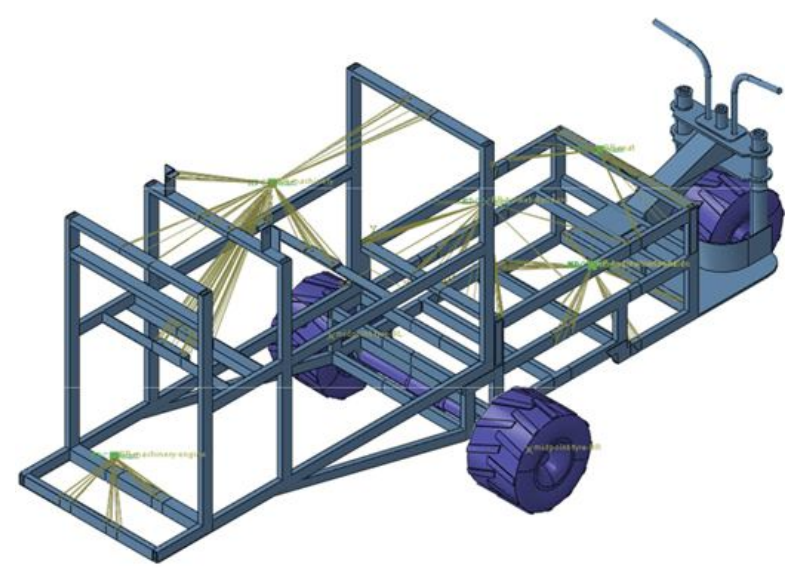

(a) ILFC machine standard position

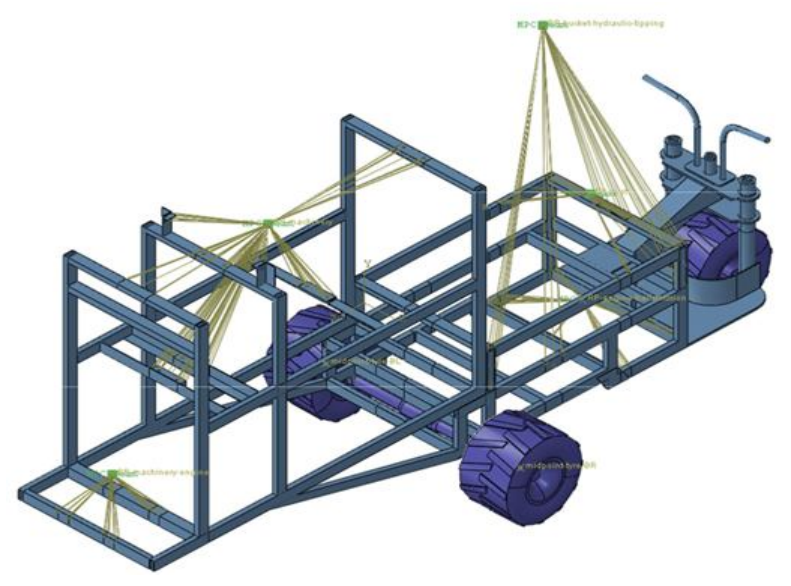

(b) ILFC machine tipping position

Figure 3: Assembly, point masses and constraints of ILFC machine position

The type of constraint between point masses and the body is multi-point beam constraint. Table 4 tabulates the value of mass assigned to each point/section.
Table 4: Point masses distribution in ILFC

\begin{tabular}{|l|c|c|c|c|}
\hline Item/Section & Material & $\begin{array}{c}\text { Mass } \\
\text { (kg) }\end{array}$ & $\begin{array}{c}\text { Type } \\
\text { of } \\
\text { mass }\end{array}$ & $\begin{array}{c}\text { Reference } \\
\text { node }\end{array}$ \\
\hline $\begin{array}{l}\text { Seat and } \\
\text { passenger }\end{array}$ & $\begin{array}{c}\text { Mild } \\
\text { steel }\end{array}$ & 107 & $\begin{array}{c}\text { Point } \\
\text { mass }\end{array}$ & RP-Seat \\
\hline $\begin{array}{l}\text { Bucket (ILFC } \\
\text { standard only) }\end{array}$ & $\begin{array}{c}\text { Mild } \\
\text { steel }\end{array}$ & 65 & $\begin{array}{c}\text { Point } \\
\text { mass }\end{array}$ & $\begin{array}{c}\text { RP bucket } \\
\text { standard }\end{array}$ \\
\hline $\begin{array}{l}\text { Hydraulic for } \\
\text { bucket ( ILFC } \\
\text { standard only) }\end{array}$ & $\begin{array}{l}\text { Mild } \\
\text { steel }\end{array}$ & 35 & $\begin{array}{c}\text { Point } \\
\text { mass }\end{array}$ & $\begin{array}{c}\text { RP } \\
\text { hydraulic } \\
\text { standard }\end{array}$ \\
\hline $\begin{array}{l}\text { Bucket and } \\
\text { hydraulic(ILF } \\
\text { C tipping } \\
\text { only) }\end{array}$ & Mild & 100 & $\begin{array}{c}\text { Point } \\
\text { mass }\end{array}$ & $\begin{array}{c}\text { RP bucket } \\
\text { hydraulic } \\
\text { tipping }\end{array}$ \\
\hline $\begin{array}{l}\text { Front engine } \\
\text { and } \\
\text { transmission }\end{array}$ & NA & 150 & $\begin{array}{c}\text { Point } \\
\text { mass }\end{array}$ & $\begin{array}{c}\text { RP } \\
\text { transmissi } \\
\text { on engine }\end{array}$ \\
\hline Machinery & Mild & 49.4 & $\begin{array}{c}\text { Point } \\
\text { mass }\end{array}$ & $\begin{array}{c}\text { RP } \\
\text { machinery }\end{array}$ \\
\hline $\begin{array}{l}\text { Engine } \\
\text { machinery }\end{array}$ & NA & 53.5 & $\begin{array}{l}\text { Point } \\
\text { mass }\end{array}$ & $\begin{array}{c}\text { RP } \\
\text { machinery } \\
\text { engine }\end{array}$ \\
\hline Load in bucket & NA & 200 & $\begin{array}{l}\text { Point } \\
\text { mass }\end{array}$ & RP bucket \\
\hline
\end{tabular}

\subsubsection{Step}

The simulation was run in two steps, starting with the initial step and followed by the static loading step. The implicit code is used by Abaqus Standard to model and analyse the simulation.

\subsubsection{Loads and Boundary Conditions}

Gravity was assigned to the whole body of the assembly with an acceleration of $9.81 \mathrm{~m} / \mathrm{s}$. Boundary condition was set as below. Encastre (fix) boundary condition was set at a few points as shown in Figure 5.

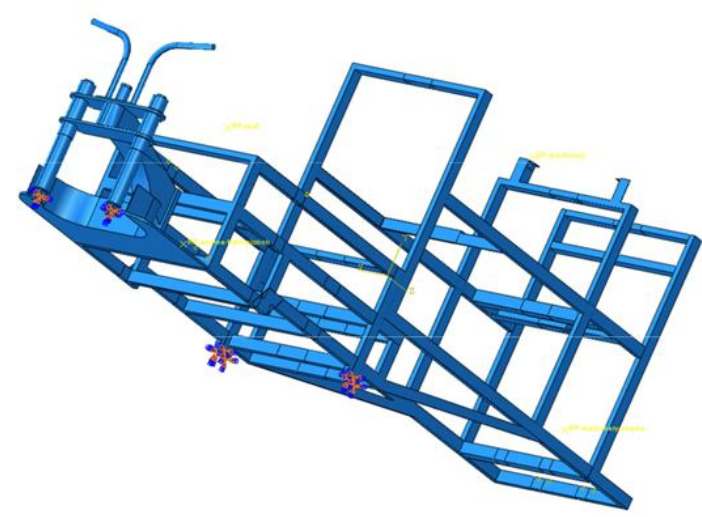

Figure 5: Fix boundary condition assigned to the area where body is connected to the shafts of the wheels 


\section{RESULT AND DISCUSSION}

\subsection{Stress Distribution}

Stress distribution for all ILFC machine condition without and with $200 \mathrm{~kg}$ loads in the bucket can be viewed in Figures 6 and 7. It can be noted that the stresses (mises) for the majority of members of the structure for all conditions were below 10 MPa which presented by the distribution colours of light blue and blue. Meanwhile the maximum mises stress was 42.43 $\mathrm{MPa}$, obtained from tipping with load results as in shown in Figure 7, which was very much different from the yield stress of steel, $350 \mathrm{MPa}$. Therefore, it can be concluded that the structure can withstand all the loads mounted on it including all the machinery, bucket, hydraulic system, seats, passengers and engines.

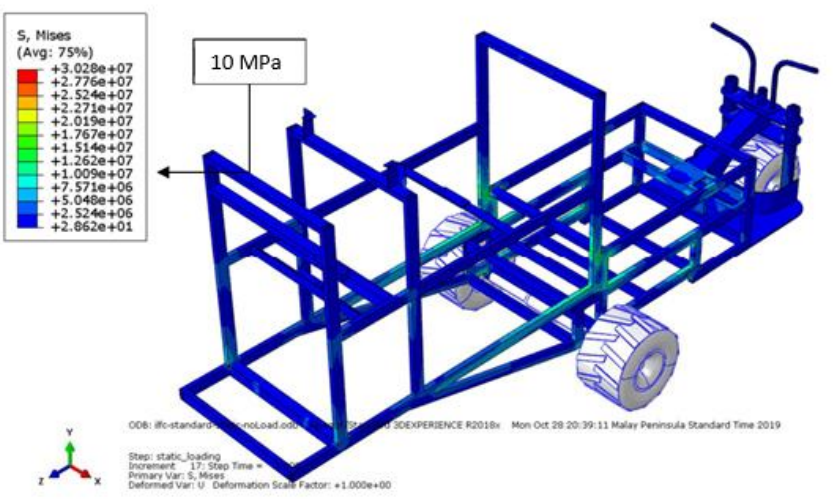

(a) ILFC machine without load

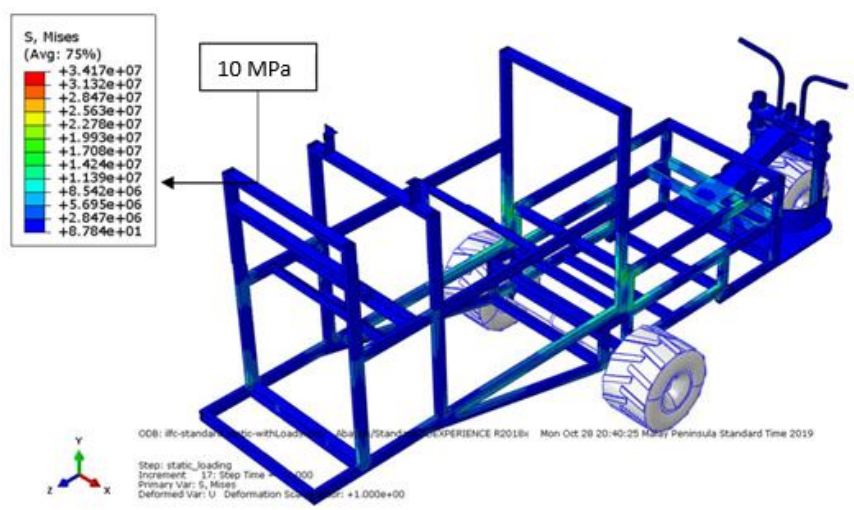

(b)ILFC machine with $200 \mathrm{~kg}$ load

Figure 6: Stress contour of ILFC machine standard position

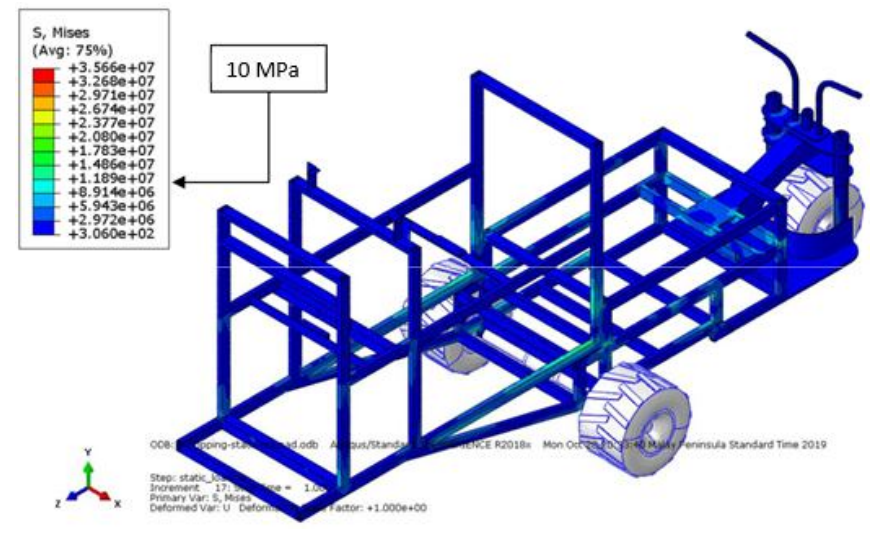

(a) ILFC machine without load

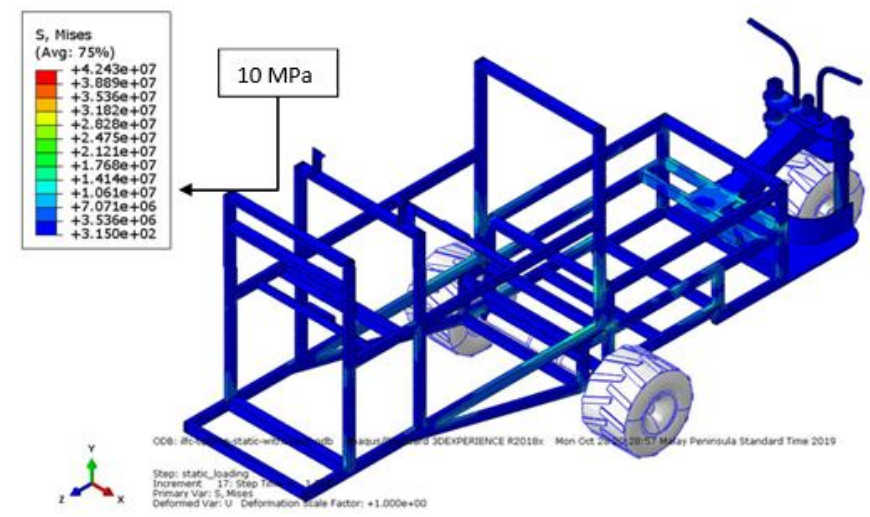

(b) ILFC machine with $200 \mathrm{~kg}$

Figure 7: Stress contour of ILFC machine tipping position

The main stress contour plots of maximum and minimum principal stress are very useful as well to give a sense of the stress flow. The stress values can also be used where worst-case compressive or tensile stresses or maximum shear stresses are needed. The principal stress contour plot can be seen in Figure 8.

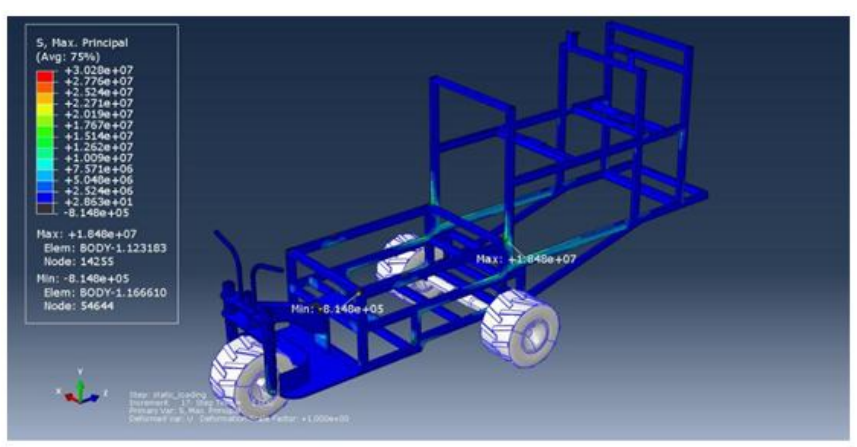

(a) ILFC machine standard position without load. 


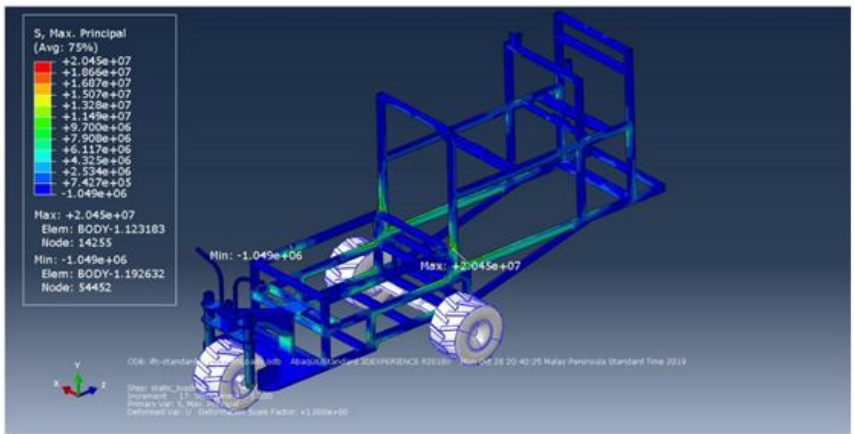

(b) ILFC machine standard position with $200 \mathrm{~kg}$ load

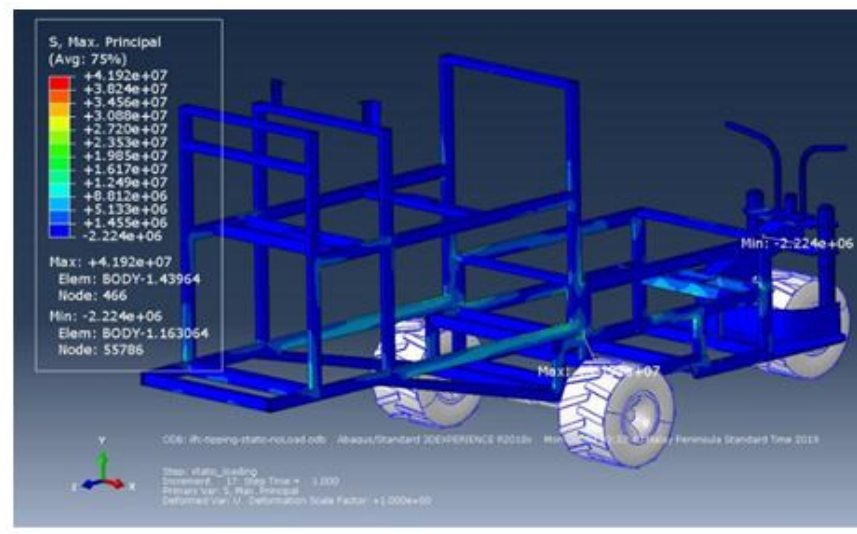

(c) ILFC machine tipping position without load

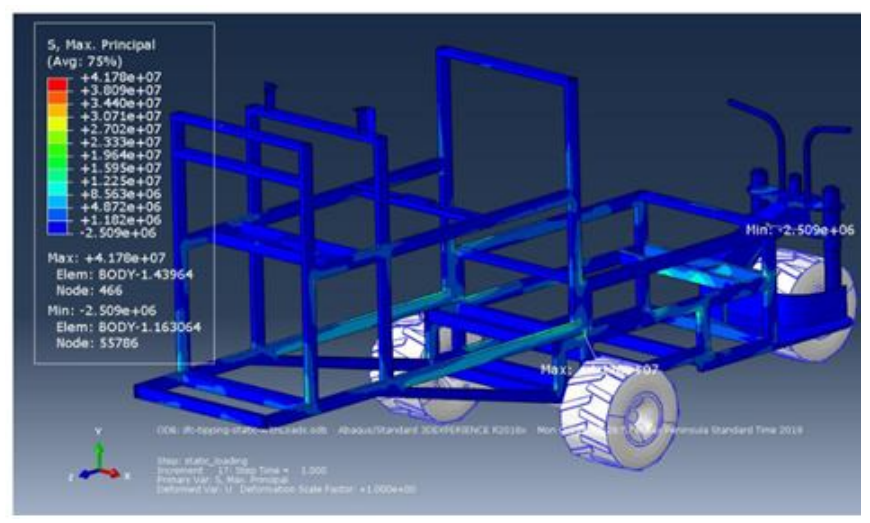

(d) ILFC machine tipping position with $200 \mathrm{~kg}$ load

Figure 8: Principal stress contour

Moreover, strain to failure for ILFC structure is in a low value of strain as compared with strain to failure of steel $0.15(1500$ $\mathrm{x} 10^{-4}$ ). The maximum true strain obtained through the simulation was about $1.719 \times 10^{-4}$ for the condition position of tipping with $200 \mathrm{~kg}$ load. In addition, for a design to be efficient, the Factor of Safety (FOS) must always equal or exceed the design safety factor, so the margin of safety exceeds than or is equal to zero. This is summarised for all simulation conditions as indicated in Table 5.
Table 5: Summary of structural integrity analysis.

\begin{tabular}{|c|c|c|c|c|}
\hline Model & $\begin{array}{l}\text { ILFC } \\
\text { standard } \\
\text { position } \\
\text { without } \\
\text { load }\end{array}$ & $\begin{array}{l}\text { ILFC } \\
\text { standard } \\
\text { position } \\
\text { with } \\
200 \mathrm{~kg} \\
\text { load }\end{array}$ & $\begin{array}{l}\text { ILFC } \\
\text { tipping } \\
\text { position } \\
\text { without } \\
\text { load }\end{array}$ & $\begin{array}{l}\text { ILFC } \\
\text { tipping } \\
\text { position } \\
\text { with } \\
\text { 200kg } \\
\text { load }\end{array}$ \\
\hline $\begin{array}{l}\text { Maximum } \\
\text { displaceme } \\
\mathrm{nt}\end{array}$ & $0.501 \mathrm{~mm}$ & $0.471 \mathrm{~mm}$ & $0.411 \mathrm{~mm}$ & $0.360 \mathrm{~mm}$ \\
\hline $\begin{array}{l}\text { Maximum } \\
\text { log strain } \\
\text { (maximum } \\
\text { principal) }\end{array}$ & $\begin{array}{l}+1.519 \mathrm{x} \\
10^{-4}\end{array}$ & $\begin{array}{l}+1.711 \mathrm{x} \\
10^{-4}\end{array}$ & $\begin{array}{l}+1.707 \mathrm{x} \\
10^{-4}\end{array}$ & $\begin{array}{l}+1.719 \mathrm{x} \\
10^{-4}\end{array}$ \\
\hline $\begin{array}{l}\text { Minimum } \\
\log \text { strain } \\
\text { (maximum } \\
\text { principal) }\end{array}$ & $\begin{array}{l}-9.727 x \\
10^{-8}\end{array}$ & $\begin{array}{l}-5.557 \mathrm{x} \\
10^{-8}\end{array}$ & $\begin{array}{l}+1.264 \mathrm{x} \\
10^{-9}\end{array}$ & $\begin{array}{l}+1.323 \mathrm{x} \\
10^{-9}\end{array}$ \\
\hline $\begin{array}{l}\text { Maximum } \\
\text { stress } \\
\text { (Mises) }\end{array}$ & $\begin{array}{l}30.28 \\
\mathrm{MPa}\end{array}$ & $\begin{array}{l}34.17 \\
\text { MPa }\end{array}$ & $\begin{array}{l}35.66 \\
\mathrm{MPa}\end{array}$ & $\begin{array}{l}42.43 \\
\text { MPa }\end{array}$ \\
\hline $\begin{array}{l}\text { Minimum } \\
\text { stress } \\
\text { (Mises) }\end{array}$ & $28.62 \mathrm{~Pa}$ & $87.84 \mathrm{~Pa}$ & $306 \mathrm{~Pa}$ & $315 \mathrm{~Pa}$ \\
\hline $\begin{array}{l}\text { Maximum } \\
\text { stress } \\
\text { (Max. } \\
\text { Principal) }\end{array}$ & $\begin{array}{l}18.48 \\
\mathrm{MPa}\end{array}$ & $\begin{array}{l}20.45 \\
\mathrm{MPa}\end{array}$ & $\begin{array}{l}41.92 \\
\mathrm{MPa}\end{array}$ & $\begin{array}{l}41.78 \\
\mathrm{MPa}\end{array}$ \\
\hline $\begin{array}{l}\text { Minimum } \\
\text { stress } \\
\text { (Max. } \\
\text { Principal) }\end{array}$ & $-0.82 \mathrm{MPa}$ & $-1.05 \mathrm{MPa}$ & $-2.22 \mathrm{MPa}$ & $-2.51 \mathrm{MPa}$ \\
\hline $\begin{array}{l}\text { Factor of } \\
\text { safety, FOS }\end{array}$ & 11.56 & 10.24 & 9.81 & 8.25 \\
\hline
\end{tabular}

\section{CONCLUSION}

The ILFC machine was designed, developed and fabricated, comprising three main components: vacuum collection component, double-layer rotating drum component, and tipping bin component. Configuration of these components required the assessment of the structural performance before the machine was deployed in the field. Results from the structural integrity analysis indicated that the structure could withstand all the loads mounted on it, due primarily to the minimum value stress induced in the material, which was less than the $350 \mathrm{MPa}$ strength of the material.

\section{REFERENCES}

1. Y. Yaw, K. Weng, and I. Norli. Strategies for improving biogas production of palm oil mill effluent (pome) anaerobic digestion: A critical review, 
Renewable Sustainable Energy Reviews, Vol. 83 (P3), pp. 2993-3006, February 2018.

2. A. Kushairi and A.R Shuib. Innovations in oil palm mechanization, The Planter, 93(1091), pp. 119-130, February 2017.

3. B. Nambiappan, A. Ismail, N. Hashim, N. Ismail, D.N. Shahari, N.A.N.N. Idris, N. Omar, K.M. Salleh, N.A.M.Hassan and A Kushairi. Malaysia: 100 years of resilient palm oil economic performance, Journal of Oil Palm Research, Vol. 30, no.1, pp. 13-25, April 2018.

4. N.R. Menon. Quality aspect of milling, Palm Oil Engineering, Bulletin Issue no.63, pp. 12-17, June 2002.

5. E.P. Darius and F.H Muhammad, Effects of collecting systems and plantation environment in debris accumulation in a collected oil palm loose fruit, International Conference Plant Physiology, pp.147-151. Bali, Indonesia, 26-28 August 2014.

6. M.S. Deraman, A.R.Shuib and M.S. Jaafer. Roller-type oil palm loose fruit picker, Information Series, MPOB TT No. 419, June 2009.

7. M. S.M. Kassim, W.I.W. Ismail, A.R. Ramli and K. Bejo. Image clustering technique in oil palm fresh fruit bunch (FFB) growth modelling, International Conference on Agricultural of Engineering (CAFEi2014), Kuala Lumpur, Malaysia, 1-3 December 2014.

8. M.R. Khalid and A.R. Shuib. Recent technologies and challenges, National Conference on Agricultural and Food Mechanization (NCAFM 2014), Kota Kinabalu, Sabah, May 20-22, 2014.

9. A.R. Shuib, M.R. Khalid and M.S. Deraman. Innovation and technologies for oil palm mechanization, Advances in Oil Palm Research, November 2010.

10. S.Sedmak, V.Grabulov and D. Momcilovic. Chronology of lost structural integrity initiated from manufacturing defects in welded structures, Structural Integrity and Life, Vol. IX, No.1, pp.39-50, October 2009.

11. G. Murray Boyd. Fracture Design Practices for Ship Structures, Fracture, Vol. V,ed. H. Liebovitz, Academic Press, New York, 1969, pp. 383-470.

12. S.Sedmak, Structural integrity - a problem of cracked component, in Proc. of First Serbian Congress on Theoretical and Applied Mechanics, Kopaonikpp, 2007, pp. 1029-1040.

13. S. Sedmak. Determining deformations and stresses by indirect testing techniques and modelling, Structural Integrity and Life, Vol.VI, No.1-2, November 2006. 